\title{
THE INTERPLAY BETWEEN JURISDICTIONAL RULES \\ ESTABLISHED IN THE EU LEGAL INSTRUMENTS IN THE FIELD OF FAMILY LAW: TESTING FUNCTIONALITY THROUGH SIMULTANEOUS APPLICATION WITH DOMESTIC LAW*
}

\author{
L'INTERAZIONE TRA LE REGOLE DI GIURISDIZIONE \\ ALL'INTERNO DEGLI STRUMENTI GIURIDICI DELL'UE \\ NELL'AMBITO DEL DIRITTO DI FAMIGLIA: LA PROVA \\ DEL FUNZIONAMENTO ATTRAVERSO L'APPLICAZIONE \\ SIMULTANEA DEL DIRITTO NAZIONALE
}

\author{
LENKA VÁLKOVÁ \\ Ph.D. Candidate in International Law \\ University of Milan
}

Recibido: 12.07.2017 / Aceptado: 15.09.2017

DOI: https://doi.org/10.20318/cdt.2017.3886

\begin{abstract}
The following article aims at testing the interrelations between the rules on: jurisdiction in divorce and parental responsibility laid down in the Brussels IIa Regulation, maintenance laid down in the Maintenance Regulation, and property regime laid down in the Regulation on Matrimonial Property Regimes and on Property Consequences of Registered Partnerships, considering a number of potentially seised Member State courts and their interactions with domestic law. For the testing, the national legal system and case law of Slovakia and Czech Republic, which require hearing of a dispute in unique proceedings (with certain differences), has been selected in order to tackle problems connected with the simultaneous application of rules established by the EU regulations and domestic procedural rules.

Keywords: multiplicity of regulations in family matters, interplay between jurisdictional rules, divorce, parental responsibility, maintenance, matrimonial property regimes, Czech and Slovak legislation.

Riassunto: Il presente contributo mira a verificare l'interazione tra le norme sulla competenza in materia di divorzio e responsabilità genitoriale stabilite dal Regolamento Bruxelles IIa, in materia di obbligazioni alimentari previste nel Regolamento sulle Obbligazioni Alimentari, e in materia di regimi patrimoniali previsti dai Regolamenti in Materia di Regimi Patrimoniali fra Coniugi e di Effetti Patrimoniali delle Unioni Registrate, prendendo in considerazione le Corti degli Stati Membri potenzialmente adite e la loro interazione con il diritto interno. Al fine di testare il funzionamento e affrontare i problemi legati all'applicazione simultanea delle norme stabilite dal diritto dell'UE e delle norme procedurali

\footnotetext{
* This article is based on a presentation given at the international conference "International Family Law Reforms" on 18 November 2016 at Universidad Carlos III de Madrid. The case law quoted in this article has been collected within the Project JUST/2014/JCOO/AG/CIVI/7729 "Planning the future of cross-border families: a path through coordination" (EUFam's) cofunded by the DG Justice within the programme "Projects to support judicial cooperation in civil or criminal matters" (Justice Programme). The public database containing case law (English summaries) is available at www.eufams.unimi.it or at the Facebook account: www.facebook.com/eufams. The case law cited in footnotes is mentioned by making reference to its 'EUFam's code', which is a unique code generated for an efficient research within the EUFam's. The opinions expressed in this article are those of the author and do not reflect the views of the European Commission.
} 
nazionali, sono stati scelti i sistemi giuridici della Slovacchia e della Repubblica ceca, che richiedono, con alcune differenze, l'audizione di una controversia in un unico processo.

Parole chiave: molteplicità dei regolamenti in diritto di familia, interazione tra le norme sulla competenza, divorzio, responsabilità genitoriale, obbligazioni alimentari, regime patrimoniale, legislazione ceca e slovacca.

Sumario: I. Multiplicity of International Legal Instruments in Different Aspects of Family Life. II. Grounds of Jurisdiction Established by the EU Regulations. 1. Jurisdiction over Divorce according to the Brussels IIa Regulation. 2. Jurisdiction over Matters of Parental Responsibility according to the Brussels IIa Regulation. 3. Jurisdiction over Maintenance according to the Maintenance Regulation. 4. Jurisdiction over Property Regime according to the Regulation on Matrimonial Property Regimes and on Property Consequences of Registered Partnerships. 5. The Interplay between Jurisdictional Grounds on Divorce, Parental Responsibility, Maintenance, and Property Regimes. III. Coherence with Domestic Law. 1. Slovakia. 2. Czech Republic. IV. Conclusions and Considerations de lege ferenda.

\section{Multiplicity of International Legal Instruments in Different Aspects of Family Life}

1. Almost five million persons immigrated to the European Union ("EU") during 2015, more than two millions of them are citizens of third States, and more than one million EU citizens immigrated to a different EU Member State. ${ }^{1}$ Increased immigration results in a growing number of international couples - two million marriages and one hundred thousand divorces took place in the EU in 2011. ${ }^{2}$ This statistical data in conjunction with the multiplicity of EU instruments in the field of family matters raise certain questions. Does transnational legislation provide for a clear and predictable framework of family law in the $\mathrm{EU}$ and is it comprehensible for international couples? Are the spouses with habitual residence in different Member States applying for divorce, custody, maintenance allowance, and liquidation and division of matrimonial property regime able to identify easily which legal instrument and which concrete provisions will be applicable ? $^{3}$ In this context, it is also important to deal with the question of the diversity of the grounds of jurisdiction established on the basis of EU legal instruments in interrelated family matters. This diversity often results in proceedings in different Member States, which may financially burden the parties (mainly the weaker parties) $)^{4}$ because they must obtain specialized legal services in all seised Member States. Finally, are such "false parallel proceedings" for divorce, parental responsibility, maintenance, and matrimonial property regimes contemplated in different Member States the best solution for the parties? ${ }^{5}$

\footnotetext{
${ }^{1}$ On the data, see Eurostat regarding Migration and migrant population statistics: http://ec.europa.eu/eurostat/statistics-explained/index.php/Migration_and_migrant_population_statistics (accessed on 7 May 2017).

2 On the data, see Eurostat regarding marriages and divorces: http://ec.europa.eu/eurostat/statistics-explained/index.php/ Marriage and divorce statistics (accessed on 7 May 2017).

${ }^{3}$ Study on the Assessment of Regulation (EC) No 2201/2003 and the Policy Options for its Amendment, Deloitte Consulting appointed by the European Commission, DG Justice, May 2015, (“Assessment Study”), p. 10, the analysis pointed out that: "the multitude, complexity and interrelationship of Union instruments in family law have led to practical difficulties, such as the lack of understanding on the part of citizens and practitioners, or confusion on the extent of jurisdiction of the competent court pursuant to the Brussels IIa Regulation on the part of the parties."

4 The maintenance creditor is considered to be a weaker party, see G. RüHL, "The Protection of Weaker Parties in the Private International Law of the European Union: A Portrait of Inconsistency and Conceptual Truancy", in Journal of Private International Law, No. 10 (3), 2014, pp. 335 -58, B. ANCEL / H. M. WATT, “Aliments sans frontières. Le règlement CE No 4/2009 du 18 décembre 2008 relatif à la compétence, la loi applicable, la reconnaissance et l'exécution des décisions et la coopération en matière d'obligations alimentaires" in Revue Critique de Droit International Privé, No. 99, 2010, p. 457, 467. However, the Brussels IIa Regulation does not provide any protection for the weaker party like the Maintenance Regulation or Brussels I-bis Regulation (e.g. consumers etc.), see J. BORG-BARTHET, Jurisdiction in matrimonial matters - Reflections for the review of the Brussels IIa Regulation (Study for the JURI Committee), Directorate general for internal policies, policy department citizen's rights and constitutional affairs, June 2016, p. 19, in this study it is affirmed that the male partner is usually in a better financial position then female in order to procure legal advice, which would lead to choice of a most favourable forum. On the weaker parties in family proceedings see also: Assessment Study, op. cit., pp. 37 - 38

${ }^{5}$ See Assessment Study, op. cit., p. 10, the analysis pointed out that citizens are interested in solving the dispute of interrelated family matters in one proceeding. For a similar approach see: D. MACDougaLL, "Transnational Litigation in Family Matters" in
} 
2. The problem of multiplicity of international legal instruments in the field of family matters is a highly discussed topic. On the EU level, the Brussels IIa Regulation ${ }^{6}$ sets out rules on jurisdiction, recognition and enforcement of judgments in divorce, legal separation or marriage annulment, and in parental responsibility matters. The Rome III Regulation ${ }^{7}$ lays down rules on the law applicable to divorce and legal separation in 16 Member States. ${ }^{8}$ And the Maintenance Regulation ${ }^{9}$ sets out rules on jurisdiction, applicable law, and recognition and enforcement of decisions in matters relating to maintenance obligations by referring to the Hague Protocol. ${ }^{10}$ In case of death of one of the spouses, the Succession Regulation ${ }^{11}$ applies and sets out rules on jurisdiction, applicable law, and recognition and enforcement of decisions. Currently, two new EU regulations on property consequences of matrimonial regimes ${ }^{12}$ and registered partnership, ${ }^{13}$ which establish a common framework for applicable law, jurisdiction, recognition and enforcement of the judgments, shall be applicable beginning on 29 January 2019 in 18 Member States. ${ }^{14}$ The international conventions adopted under the auspices of the Hague Conference on the Private International Law also regulate rules in different fields of family matters as to the applicable law, jurisdiction, recognition and enforcement of the judgments between contracting states; furthermore, the major part of the contracting states are the Member States. ${ }^{15}$ Other multilateral, international conventions on family matters were ratified between non-Member States and thus, do not affect the rules set out in EU regulations. ${ }^{16}$ And last, but not least, when the EU regulations, the international conventions, or the bilateral agreements are not applicable, the domestic acts on private international law of the Member State come into play.

N. V. Lowe /G. Douglas (eds.), Families Across Frontiers, The Hague, Martinus Nijhoff Publishers, 1996, p. 63; or G. MorR / P.R. Beaumont, "Brussels Convention II: a new private international law instrument in family matters for the European Union or the European Community?", European Law Review, No. 20(3), 1995, p. 9, according to the authors, the ideal solution for the court is a hearing on the divorce connected with matrimonial property and the financial and social aspects relating to children of the marriage.

${ }^{6}$ Council Regulation (EC) No 2201/2003 of 27 November 2003 concerning jurisdiction and the recognition and enforcement of judgments in matrimonial matters and the matters of parental responsibility, repealing Regulation (EC) No 1347/2000, OJEU L 338, 23 December 2003, (“Brussels IIa Regulation”).

${ }^{7}$ Council Regulation (EU) No 1259/2010 of 20 December 2010 implementing enhanced cooperation in the area of the law applicable to divorce and legal separation, OJEU L 343, 29 December 2010, ("Rome III Regulation").

8 Belgium, Bulgaria, Germany, Greece, Spain, France, Italy, Latvia, Lithuania, Luxembourg, Hungary, Malta, Austria, Portugal, Romania, and Slovenia and by Decision (EU) 2016/1366 the Rome III Regulation will be applicable in Estonia from 11 February 2018.

9 Council Regulation (EC) No 4/2009 of 18 December 2008 on jurisdiction, applicable law, recognition and enforcement of decisions and cooperation in matters relating to maintenance obligations, OJEU L 7, 10 January 2009 ("Maintenance Regulation").

${ }^{10}$ Hague Protocol of 23 November 2007 on the law applicable to maintenance obligations.

11 Regulation (EU) No 650/2012 of the European Parliament and of the Council of 4 July 2012 on jurisdiction, applicable law, recognition and enforcement of decisions and acceptance and enforcement of authentic instruments in matters of succession and on the creation of a European Certificate of Succession, OJEU L 201, 27 July 2012.

12 Council Regulation (EU) 2016/1103 of 24 June 2016 implementing enhanced cooperation in the area of jurisdiction, applicable law and the recognition and enforcement of decisions in matters of matrimonial property regimes, OJEU L 183, 8 July 2016 ("Regulation on Matrimonial Property Regimes").

${ }_{13}$ Council Regulation (EU) 2016/1104 of 24 June 2016 implementing enhanced cooperation in the area of jurisdiction, applicable law and the recognition and enforcement of decisions in matters of the property consequences of registered partnerships, OJEU L 183, 8 July 2016, ("Regulation on Property Consequences of Registered Partnerships").

${ }^{14}$ Austria, Belgium, Bulgaria, Cyprus, the Czech Republic, Germany, Greece, Spain, France, Croatia, Italy, Luxembourg, Malta, the Netherlands, Portugal, Slovenia, Finland, and Sweden.

15 Convention of 24 October 1956 on the law applicable to maintenance obligations towards children, (14 Contracting states, 10 of them are EU Member States), on the status table see: https://www.hcch.net/en/instruments/conventions/status-table/?cid=37; Convention of 15 April 1958 concerning the recognition and enforcement of decisions relating to maintenance obligations towards children (20 Contracting states, 14 of them are EU states), on the status table see: https://www.hcch. net/en/instruments/conventions/status-table/?cid=38; Convention of 2 October 1973 on the Recognition and Enforcement of Decisions Relating to Maintenance Obligations, (24 Contracting states, 18 of them are EU Member States), on the status table see: https://www.hcch.net/en/instruments/conventions/status-table/?cid=85. Convention of 2 October 1973 on the Law Applicable to Maintenance Obligations, (15 Contracting states, 12 of them are EU Member States), on the status table see: https:// www.hcch.net/en/instruments/conventions/status-table/?cid=86; Convention of 19 October 1996 on Jurisdiction, Applicable Law, Recognition, Enforcement and Co-operation in Respect of Parental Responsibility and Measures for the Protection of

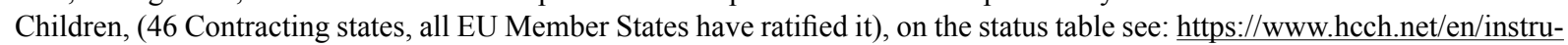
ments/conventions/status-table/?cid=70, Convention of 23 November 2007 on the International Recovery of Child Support and Other Forms of Family Maintenance, (35 Contracting states, in 2014 was ratified by the EU).

16 e.g., Inter-American Convention on Support Obligations, on the contracting states see: http://www.oas.org/juridico/ english/sigs/b-54.html. 
3. As a consequence of the multiplicity of legal instruments impacting different topics of family life, the specific aspects governing the dispute must be evaluated. First, the questions of applicable law and jurisdiction need to be analysed and separated. Secondly, it must be properly determined if the claim falls within the scope of a specific legal instrument. At that moment, the qualification problem of legal categories must be faced, which arise not only in relation with third States in the presence of international conventions, but also in purely EU disputes due to the fragmentation of EU legislation. ${ }^{17}$ Although the EU regulations in family matters contain definitions of certain notions ${ }^{18}$, there is a need for autonomous interpretation. ${ }^{19}$ Thus, it is not always possible to prevent the difficulties connected with the qualification and delineation between regulations and specific legal concepts in practise within Member States. ${ }^{20}$

4. The aim of this article is not to analyse only the interplay between the current jurisdictional rules on divorce, parental responsibility, maintenance obligations, and property consequences of matrimonial regimes and registered partnerships within the EU regulation. ${ }^{21}$ This article will also assess whether such jurisdictional rules provide for a clear legal framework in different fields of family life in the EU, and if the rules are comprehensible for individuals without any legal background. Secondly, this article will concern the question of "false parallel proceedings" of correlated family matters, i.e., the need to seise multiple Member States by virtue of the rules established by the EU regulations, even if one family "package" would be a reasonable solution. Thirdly, the mixed application of the respective jurisdictional rules laid down in different EU regulations and national legislation will be tested for their functionality. The application of EU rules will be examined on the basis of case law and national legislation of two preselected Member States - Slovakia and Czech Republic. The Slovak legal system requires courts to hear all of the interrelated family questions in a unique proceeding. According to Czech Law, the previous determination of custody rights and maintenance obligation toward the children is a precondition for issuing a subsequent judgment for divorce. Finally, possible solutions will be considered and proposed.

17 The problem of qualification developed already in the 19th century by F. KAHN, "Gesetzkollisionen. Ein Beitrag zur Lehre des internationalen Privatrechts" in Jherings Jahrbücher, No. 30, 1891 and E. BARTIN, "De l'impossibilité d'arriver à la suppression définitive des conflits de loi" in Journal de droit international privé, Clunet, No 24, 1897, pp. 225.

18 See e.g., Article 2 of the Brussels IIa Regulation or Maintenance Regulation.

19 See ECJ 20 March 1997, Jackie Farrell, C295/95, ECLI:EU:C:1997:168; 2 April 2009, A, C523/07; 16 July 2009, Hadadi, C168/08, ECLI:EU:C:2009:474; 9 November 2010, Purrucker, C296/10, ECLI:EU:C:2010:665; 6 December 2010, Mercredi, C497/10 PPU, ECLI:EU:C:2010:829.

20 See B. Hess in B. Hess; T. Pfeiffer; P. Schlosser, The Brussels I-Regulation (EC) No 44/2001: the Heidelberg Report on the Application of Regulation Brussels I in 25 member states; (study JLS/C4/2005/03), München, Beck, 2008, p. 25 ("Heidelberg Report"), the author pointed out difficulties concerning the distinction between maintenance proceedings and proceedings concerning the matrimonial property regime. On the general interpretation of the concept concerning maintenance matters see: Report by Professor Dr Peter Schlosser on the Convention of 9 October 1978 on the Association of the Kingdom of Denmark, Ireland and the United Kingdom of Great Britain and Northern Ireland to the Convention on jurisdiction and the enforcement of judgments in civil and commercial matters and to the Protocol on its interpretation by the Court of Justice, OJEC C 59, 5 March 1979, paras 91-97 (“Schlosser Report”). See also I. VIARENGO, "Rapporto sull'applicazione in Italia del regolamanto (CE) n. 4/2009, del 18 dicembre relativo alla competenza, alla legge applicabile, al riconoscimento e all'esecuzione delle decisioni e alla cooperazione in matera di obbligazoni alimentari" in S. Bariatti, I. Viarengo, and F. C. Villata (eds.), $L a$ giurisprudenza italiana sui regolamenti europei in materia civile e commerciale e di famiglia, Milano, Wolters Kluwer, 2016, p. 406. In Italy, the notion of maintenance obligations specified in Article 433 of the Italian Civil Code is narrower than the autonomous notion used in the Maintenance Regulation. However, according to the actual Italian case law, the maintenance obligation of the Maintenance Regulation includes the legal concept of "alimony" ("alimenti"), "maintenance" ("mantenimento"), and the divorce contribution ("assegno divorzile"). In detail, see Corte di Cassazione, 24 July 2003 No 1152, regarding the necessity to interpret the notion of maintenance autonomously, or on the specific issues which should be covered by the Maintenance Regulation; Tribunale di Belluno, 30 December 2011, EUFam's number: ITF20111230; Tribunale di Roma, 5 November 2013, EUFam's number: ITF20131105; Tribunale di Belluno, 12 November 2013, EUFam's number: ITF20131112 and 23 December 2014, EUFam's number: ITF20141223. In Spain, maintenance between ex-spouses does not have a maintenance nature under Spanish substantive law, but it is included in international matters; in this regard see the judgment of Audiencia Provincial Barcelona, 8 April 2014, No. 260/2014, EUFam's number: ESS20140408; Audiencia Provincial Barcelona, 12 November 2013, No. 777/2013, EUFam's number: ESS20131112; Audiencia Provincial Santa Cruz de Tenerife 7 October 2011, No. 429/2011, EUFam's number: ESS20111007.

21 The aim of the article is to examine the jurisdictional rules contained in the EU regulations, but not in international conventions in family matters. Also, the applicable law is not the subject of examination by this article. 


\section{Grounds of Jurisdiction Established by the EU Regulations}

5. In order to proceed with the considerations in this article, it is opportune to remember the grounds of jurisdiction on: (i) divorce; (ii) parental responsibility laid down by the Brussels II, a Regulation with reference to amendments proposed by the Commission in June 2016; ${ }^{22}$ (iii) maintenance obligations laid down by the Maintenance Regulation; and (iv) property regimes laid down by new Regulations on Property Regimes. ${ }^{23}$

\section{Jurisdiction over Divorce according to the Brussels IIa Regulation}

6. Article 3 of the Brussels IIa Regulation contains a general jurisdictional rule on divorce, legal separation, and marriage annulment. Six out of seven jurisdictional grounds are based on habitual residence.$^{24}$ In particular, jurisdiction might be based on: the spouses' common, habitual residence; the spouses' common, last habitual residence, insofar as one of them still resides there; the respondent's habitual residence; in the event of a joint application, the habitual residence of either of the spouses; the applicant's habitual residence, if he or she resided there for at least a year immediately before the application; and the applicant's habitual residence, if he or she resided there for at least six months immediately before the application and is a national of the Member State in question. The fifth and sixth indent of Article 3, lett. a), was the subject of discussion because of the possible easy abuse by the parties. ${ }^{25}$ The last jurisdictional ground is based on the forum patriae communis of EU nationals, may have a minimum real connection with the case, and might fragment jurisdiction. ${ }^{26}$

7. All seven alternative jurisdictional grounds established in Article 3 have been criticized, since no hierarchy between them has been adopted and are too claimant friendly. ${ }^{27} \mathrm{~A}$ lack of uniformity in choice-of-law rules causes forum shopping and provides a mechanism for a party to choose the applicable law. ${ }^{28}$ The plaintiff's possibility to choose the forum due to the lis pendens rule often results in

22 Proposal for a Council Regulation on jurisdiction, the recognition and enforcement of decisions in matrimonial matters and the matters of parental responsibility, and on international child abduction (recast), $\operatorname{COM(2016)} 411$ final, 30 June 2016 , ("Proposal of the Brussels IIa Regulation").

${ }^{23}$ Regulation on Matrimonial Property Regimes and Regulation on Property Consequences of Registered Partnerships collectively referred as "Regulations on Property Regimes" shall apply from 29 January 2019, thus considerations in this regard will be limited.

${ }^{24}$ The Brussels IIa Regulation does not contain any definition of habitual residence; on the autonomous concept of habitual residence of the child see ECJ, $A$, C-523/07, op. cit., or Mercredi, C-497/10 PPU, op. cit.

${ }^{25}$ See Explanatory Report on the Convention, drawn up on the basis of Article K.3 of the Treaty on European Union, on Jurisdiction and the Recognition and Enforcement of Judgments in Matrimonial Matters (approved by the Council on 28 May 1998) prepared by Dr Alegría Borrás, OJEC C 221, 16 July 1998, para. 32 ("Borrás Report”); D. Hodson, "What is jurisdiction for divorce in the EU? The contradictory law and practice around Europe.", IFL, September 2014, pp. 170; R. BARATTA, "Lo scioglimento del vincolo coniugale nel diritto comunitario", in S. M. CARBONE, I. QueIRolo, Diritto di famiglia e Unione europea, Torino, Giappichelli, 2008, p. 182, according to the author it would not be unreasonable to eliminate these two connecting factors since they do not represent a real connection with matrimonial life.

26 On the criticism of nationality principle see: B Hess, "Die Verordnung Nr. 4/2009/EG zum Unterhaltsrecht" in C. SснміDт (ed), Internationale Unterhaltsrealisierung, Nomos, 31, § 1 para $11 \mathrm{n} 33$, 2011. On problems regarding dual citizenship, see ECJ, Hadadi, C-168/08, op. cit., or S. BARIATTI, "Multiple Nationals and EU Private International Law - Many Questions and Some Tentative Answers." in Yearbook of Private International Law, 2011, pp. 1 -19 or T. KRUGER / J. VERHELLEN, "Dual Nationality = Double Trouble?", in Journal of Private International Law, No. 7, 2011, pp. 601 -626.

27 An explanation on the lack of hierarchy see: Borrás Report, op. cit., para. 28, or the Opinion of Advocate General Kokott, 12 March 2009, Hadadi, ECLI:EU:C:2009:152, paras 58, 59, confirming the flexible choice of jurisdiction. For the need of establishment of a hierarchy between jurisdictional grounds, see Responses to the Questionnaire of EUFam's available at: http://www.eufams.unimi.it/2017/06/01/report-outcomes-online-questionnaire/ (accessed on 6 June 2017), almost $62 \%$ of respondents answered that the efficacy of Article 3 of the Brussels IIa Regulation should be improved by establishing a hierarchy among the existing grounds; see also G. MoIR, P.R. BEAumont, "Brussels Convention II: a new private international law instrument in family matters for the European Union or the European Community?", op. cit. p. 11, according to the authors, a possible solution would be introducing a hierarchy of rules, starting out with the habitual residence of both parties and gradually decreasing.

${ }^{28}$ However, as already mentioned, the Rome III Regulation is applicable only in 16 Member States. 
abusive procedural tactics known as the "rush to court". ${ }^{29}$ Rome III Regulation may be perceived as a partial solution to abusive procedural tactics, or, on the contrary, may increase such tactics. ${ }^{30}$

8. Other jurisdictional grounds are regulated in Article 4 relating to counterclaims and in Article 5 relating to conversion of legal separation into divorce. Article 7 of the Brussels IIa Regulation on residual jurisdiction refers to the national rules if no court of a Member State has jurisdiction pursuant to Articles 3, 4, and 5 of the Regulation. The Commission proposed to delete the division between Article 6 and 7, which posed many interpretative issues. ${ }^{31}$ But unfortunately forum necessitatis, or ensuring access to Member State court for a spouse who lives in a third State, which retains strong links with a certain Member State (e.g., nationality or habitual residence lasting for a certain period), was not introduced. ${ }^{32}$ Other jurisdictional rules on divorce will remain unchanged, since the Proposal on the Brussels IIa Regulation maintains the status quo. ${ }^{33}$ As a consequence, problems regarding abusive legal tactics connected with forum shopping will remain unresolved for now. Also, requests by Member States to introduce into the Brussels IIa Regulation the choice-of-court agreement for divorce proceedings has not been heeded in the Proposal. ${ }^{34}$

\section{Jurisdiction over Matters of Parental Responsibility according to the Brussels IIa Regulation}

9. On the contrary, Article 8 of the Brussels IIa Regulation provides for only one jurisdictional ground in parental responsibility matters. In particular, the connecting factor is habitual residence of the child at the time the Member State court is seised. ${ }^{35}$ This rule should ensure that the most appropriate Member State court is seised in accordance with the principle of the best interest of the child, based on the proximity criterion. The Commission proposed to abolish perpetuatio fori in Article 8 (Article 7 of the Proposal). According to the Commission, this action should deepen the proximity principle in case of a lawful relocation of the child, ${ }^{36}$ but the European Parliament's Committee on Legal Affairs proposed to move perpetuatio fori back. ${ }^{37}$

${ }^{29}$ On forum shopping in family matters and the "rush to court" see e.g. ECJ, Hadadi, op. cit., para. 57; M. Ní SHúiLLEABHÁIN, "Ten Years of European Family Law: Retrospective Reflection from a Common Law Perspective", in ICLQ, n. 59, 2010, pp. 1021 -1053; M. Ní ShúIlleabháin, Cross-border divorce law. Brussels II bis, New York, Oxford University Press, 2010, pp. 149; J. Meeusen, "System shopping in European private international law in family matters" in J. MeEuSEN, M. Pertegás, G. Straetmans, F. Swennen (eds.), International Family Law for the European Union, Antwerpen - Oxford, Intersentia, 2007, pp. 239; N. Dethloff, "Arguments for the Unification and Harmonisation of Family Law in Europe" in K. Boele-Woelki, Perspectives for the Unification and Harmonisation of Family Law in Europe, Antwerpen - Oxford - New York, Intersentia, 2003, pp. 51.

${ }^{30}$ A. BonomI, "Litigation in family matters: is it possible to reconcile uniformity and application of lex fori?", in $I F L$, March 2012, pp. 11, according to the author the jurisdictional grounds contained in Article 3 of the Brussels IIa Regulation are same as in the Rome III Regulation; as a consequence the court may apply lex fori that will encourage even more forum shopping. See also M. JänTERä-JAREBORG, "Unification of international family law in Europe”, in K. Boele-Woelki, Perspectives for the Unification and Harmonisation of Family Law in Europe, Antwerpen - Oxford - New York, Intersentia, 2003, pp. 207.

${ }^{31}$ See Article 6 of the Proposal of the Brussels IIa Regulation The interpretation problem arises in connection with the case of ECJ, 29 November 2007, Sundelind Lopez, C-68/07, ECLI:EU:C:2007:740.

32 See Article 6 of the Proposal of the Brussels IIa Regulation. See also A. NuYTs, Study on Residual Jurisdiction (Review of the Member States' Rules concerning the "Residual Jurisdiction" of their courts in Civil and Commercial Matters pursuant to the Brussels I and II Regulations), 6 July 2007, para 124-127 where it is pointed out that in 13 Member States citizenship is not a valid ground of jurisdiction. During the national EUFam's conferences, it was proposed to replace Article 7 with a forum necessitatis rule, see e.g. German report on good practises, p. 3, available at: http://www.eufams.unimi.it/2017/01/10/ german-report-on-good-practices, (accessed on 17 May 2017).

33 Proposal of the Brussels IIa Regulation, p. 10.

34 See Assessment Study, op. cit., p. 12, the study highlighted the fact that 139 of 163 respondents complained that the Brussels IIa Regulation does not contain a rule enabling the possibility to designate the court by the spouses for divorce.

35 The ECJ did not provide an interpretation as to the habitual residence of the spouses.

${ }^{36}$ See Recital No 15 and Article 7 of the Proposal of the Brusses IIa Regulation.

37 The Draft Report on the proposal for a Council regulation on jurisdiction, the recognition and enforcement of decisions in matrimonial matters and the matters of parental responsibility, and on international child abduction (recast) $(\mathrm{COM}(2016) 0411$ - C8-0322/2016 - 2016/0190(CNS)), 9 May 2017. 
10. Exceptions to the general rule can be found in: Article 9 dealing with the child's previous habitual residence; Article 10 dealing with child abduction; and Article 12 dealing with prorogation of jurisdiction. Sometimes other Member State courts appear to be better placed, such as in Article 13 concerning the presence of the child, or pursuant to Article 14 concerning residual jurisdiction, or finally under Article 15 concerning the transfer of the case to better placed Member State court; as a consequence, Member State courts may establish jurisdiction by virtue of these provisions. The Commission has not presented significant changes in the Proposal regarding parental responsibility matters. ${ }^{38}$

\section{Jurisdiction over Maintenance according to the Maintenance Regulation}

11. Maintenance and other financial matters are excluded from the scope of the Brussels IIa Regulation and rules on jurisdiction are contained in the Maintenance Regulation. The jurisdictional grounds laid down in Articles 2 and 5 n. 2 of the Brussels I Regulation ${ }^{39}$ gave rise to Article 3 of the Maintenance Regulation with some exceptions. ${ }^{40}$ The Maintenance Regulation provides for four jurisdictional grounds in Article 3. The first two jurisdictional grounds set out in letters a) and b) of Article 3 refer to the habitual residence of the defendant and creditor. Another two jurisdictional grounds refer to the situation when maintenance is ancillary to the proceedings as to the status of a person (Article 3 lett. c)) or as to the parental responsibility (Article 3 lett. d)), unless that jurisdiction is based solely on the nationality of one of the parties. Thus, a Member State court, which has established jurisdiction for divorce or parental responsibility, may entertain proceedings also for maintenance matters. However, the hierarchy between the jurisdictional grounds contained in Article 3 of the Maintenance Regulation is not as well determined like in Article 3 of the Brussels IIa Regulation - the choice of the competent Member State courts by a maintenance creditor should result in the most favourable court by virtue of principle a favore creditoris.

12. Besides these four jurisdictional grounds set out in Article 3, the spouses may conclude choice-of-court agreements in favour of other Member States. Protection of the maintenance creditor is guaranteed by the limitation of party autonomy. The choice of court is enabled in favour of Member States where a specific connecting factor occurs (habitual residence, last habitual residence, or nationality), ${ }^{41}$ and is excluded regarding a maintenance obligation towards a child under the age of $18 .{ }^{42}$ Moreover, the Member State may establish jurisdiction upon appearance of the defendant (Article 5), ${ }^{43}$ or in cases when proceedings cannot be reasonably brought in a third State (Article 7 -forum necessitatis), or may establish so-called subsidiary jurisdiction based on the common nationality of the spouses upon fulfilment of the requirements established by Article $6 .{ }^{44}$

\footnotetext{
38 Proposal on Brussels IIa Regulation, p. 10, admits that: "With regard to parental responsibility matters, the preferred option is for an EU intervention as motivated by the scale and urgency of the problem."

39 Council Regulation (EC) No 44/2001 of 22 December 2000 on jurisdiction and the recognition and enforcement of judgments in civil and commercial matters, OJEC L 12, 16 January 2001, ("Brussels I Regulation").

40 On jurisdictional grounds provided for in Article $5 \mathrm{n}$. 2 of the Brussels I Regulation and Proposal on the Maintenance Regulation see: I. VIARENGO, "La disciplina comunitaria delle obbligazioni alimentari e il rapporto con la nuova normative convenzionale" in S. M. Carbone, I. QueIrolo, Diritto di famiglia e Unione europea, Giappichelli, Torino, 2008, p. 364.

${ }^{41}$ U.P. Gruber, "Die neue EG-Unterhaltsverordnung" in Praxis des Internationalen Privat- und Verfahrensrechts, No. 2 , 2010, p. 128-139.

42 See G. RüHL, "The Protection of Weaker Parties in the Private International Law of the European Union: A Portrait of Inconsistency and Conceptual Truancy", op. cit., pp. 348

43 A child, as a maintenance creditor, is protected from concluding a choice-of-court agreement; however a rule on submission of appearance is applied also in disputes concerning child maintenance allowance.

${ }^{44}$ On the jurisdictional grounds established by the Maintenance Regulation in more details see: F. Pocar, "La disciplina comunitaria della giurisdizione in tema di alimenti: il regolamento $4 / 2009$ " in M. C. BARUFFI, R.C. PANICO, Le nuove competenze comunitarie. Obbligazioni alimentari e successioni., Milano, Cedam, 2009, pp. 5; F.C. VILlata, "Obblighi alimentari e rapporti di famiglia secondo il regolamento n. 4/2009", Rivista di Diritto Internazionale, No. 2011, pp. 731 - 777; F. PoCAR, I. VIARENGO, "Il regolamento (CE) n. 4/2009 in materia di obbligazioni alimentari", in Rivista di Diritto Internazionale Privato e Processuale, No. 4, 2009, pp. 805-829.
} 


\section{Jurisdiction over Property Regimes according to the Regulation on Matrimonial Property Re- gimes and on Property Consequences of Registered Partnerships}

13. Two regulations - Regulation on Matrimonial Property Regimes and Regulation on Property Consequences of Registered Partnerships implement enhanced cooperation in the area of jurisdiction, applicable law, and the recognition and enforcement of decisions involving the property regimes of international couples. These regulations cover both matrimonial property regimes and the property consequences of registered partnerships and shall apply in 18 Member States after 29 January 2019. ${ }^{45}$

14. The Regulation on Matrimonial Property Regimes laids down several rules concerning jurisdictional grounds ${ }^{46}$ In the first place, the jurisdiction of the matrimonial property regime follows the jurisdiction for divorce under the Brussels IIa Regulation. ${ }^{47}$ This does not apply when a Member State court established jurisdiction according to the fifth or sixth indents of Article 3, par. 1, lett. a), 5 or 7 of the Brussels IIa Regulation; however, in such cases the concentration of divorce and matrimonial property proceedings is possible upon agreement of the spouses. ${ }^{48}$ Moreover, electio foris is permitted in favour of a court of another Member State, such as the place of conclusion of the marriage ${ }^{49}$ or the place whose law is applicable to the dispute and guarantees conformity between ius and forum. ${ }^{50}$ When jurisdiction cannot be established in accordance with previous articles or in other cases, Article 6 of the Regulation on Matrimonial Property Regimes provides for the following hierarchy of jurisdictional grounds: the spouses' habitual residence; the spouses' last habitual residence, if one of them still resides there; the respondent's habitual residence; and the spouses' common nationality. The jurisdictional grounds correspond to the first three indents of Article 3 par. 1, lett. a) and lett. b), but the last three indents of the Brussels IIa Regulation are not included. This hierarchical list of jurisdictional grounds is not completely in line with the Brussels IIa Regulation, and provides for alternative fora. This approach might lead to proceedings in front of different venues for the matrimonial property regime versus the divorce.

15. The Regulation on Property Consequences of Registered Partnerships provides for similar rules. ${ }^{51}$ However, the concentration of proceedings for the dissolution and annulment of registered partnerships and for liquidation and division of property is possible only upon common agreement. ${ }^{52}$ Other jurisdictional grounds practically mirror the provision of the Regulation on Matrimonial Property Regimes with two exceptions: when there is a choice of court, the parties may designate also the courts

45 Some Member States indicated difficulties accepting the Proposal on Property Consequences of Registered Partnerships. On 3 December 2015, the Council stated that unanimity was not possible within a reasonable time, but 17 Member States between December 2015 and February 2016 expressed willingness to establish enhanced cooperation. Cyprus expressed on 18 March 2016 its wish to participate in the establishment of enhanced cooperation. Estonia announced its intention to take part in the cooperation after its adoption.

${ }^{46}$ On the comments to the proposal to Regulations on Property Regimes see I. VIarengo, "The EU Proposal on Matrimonial Property Regimes - Some General Remarks", Yearbook of Private International Law, Sellier European Law Publishers, No 13, 2011, pp. 199-215; on the first overlook of jurisdictional grounds established by Regulations on Property Regimes see S. Marino, "Strengthening the European Civil Judicial Cooperation: The Patrimonial Effects of Family Relationships", in Cuadernos de Derecho Transnacional, Vol. 9, No 1, 2017, pp. 265-284.

47 Article 5, par. 1 of Regulation on Matrimonial Property Regimes.

48 Article 5, par. 2 of Regulation on Matrimonial Property Regimes.

49 Article 7 of Regulation on Matrimonial Property Regimes.

50 The parties may designate a court of the Member State whose law is applicable, pursuant to Article 22 on choice of law, or failing a choice of law, Article 26, para 1 lett. a) or b) applies. The articles refer to: the law of the State where the spouses, future spouses, or one of them, is habitually resident at the time the agreement is concluded (Article 22, para 1, lett. a); the law of a State of nationality of either spouse or future spouse at the time the agreement is concluded (Article 22, para 1, lett. b)); the law applicable to the spouses' first common habitual residence after the conclusion of the marriage (Article 26, par. 1, lett. a)); and the law applicable to the spouses' common nationality at the time of the conclusion of the marriage (Article 26, par. 1, lett. b)).

${ }^{51}$ On the Proposal on the Property Consequences of Registered Partnerships see C. G. BeILfuss, "The Proposal for a Council Regulation on the Property Consequences of Registered Partnerships" in Yearbook of Private International Law, Sellier European Law Publishers, No 13, 2011, pp. 183-198.

52 Article 5 of the Regulation on Property Consequences of Registered Partnerships. 
of the Member State under whose law the registered partnership was created ${ }^{53}$ and in the absence of a choice of court, the last jurisdictional ground is added to the end of hierarchical list and refers to the law where the partnership is registered. ${ }^{54}$

16. Furthermore, both Property Regimes Regulations provide for other jurisdictional grounds based on the appearance of the defendant (Article 8), alternative jurisdiction (Article 9), subsidiary jurisdiction (Article 10), and also for forum necessitatis (Article 11).

\section{The Interplay between Jurisdictional Grounds on Divorce, Parental Responsibility, Maintenan- ce, and Matrimonial Property Regimes}

17. The diversity of jurisdictional grounds in divorce, parental responsibility, maintenance matters, and matters concerning property consequences of marriage and registered partnerships may result in proceedings in multiple Member States for interrelated family matters. This chapter will analyse the possible scenarios in this regard and demonstrate the complexity that results when a number of Member State courts are seised in family matters.

Julia and Michael, Austrian nationals, (Julia has dual citizenship - Spanish and Austrian) met in Italy and they stayed there after their studies. They got married during their holiday in Paris and they gave birth to Anna (Anna has Spanish and Austrian citizenship as well). Afterwards, Julia moved back to Spain with Anna, but Martin moved for work to Germany (both spouses lived in these respective countries for 1 year). The marriage did not go well and motions for divorce, parental responsibility, maintenance obligation, and liquidation of matrimonial property regime were filed.

The subsequent table shows the number of potentially seised Member State courts.

\begin{tabular}{|l|l|l|l|l|l|}
\hline & \multicolumn{1}{|c|}{ Austria } & \multicolumn{1}{c|}{ Spain } & \multicolumn{1}{c|}{ Germany } & \multicolumn{1}{c|}{ Italy } & France \\
\hline $\begin{array}{l}\text { DIVORCE } \\
\text { (Brussels } \\
\text { IIa Regulation) }\end{array}$ & $\begin{array}{l}\text { General rule: } \\
\text { Art 3 par 1 lett. } \\
\text { b) }\end{array}$ & $\begin{array}{l}\text { General rule: } \\
\text { Art 3, par 1 lett. } \\
\text { a) 3rd, 4th, 5th } \\
\text { or 6th indent }\end{array}$ & $\begin{array}{l}\text { General rule: } \\
\text { Art 3 par 1 lett. } \\
\text { a) 3rd, 4th or } \\
\text { 6th indent }\end{array}$ & & \\
\hline $\begin{array}{l}\text { PARENTAL } \\
\text { RESPONSIBILITY } \\
\text { (Brussels IIa } \\
\text { Regulation) }\end{array}$ & $\begin{array}{l}\text { Prorogation of } \\
\text { jurisdiction: } \\
\text { Art 12 } \\
\text { Transfer to the } \\
\text { court: Art 15 }\end{array}$ & $\begin{array}{l}\text { General rule: } \\
\text { Art 8 }\end{array}$ & $\begin{array}{l}\text { Prorogation of } \\
\text { jurisdiction: } \\
\text { Art 12 } \\
\text { Transfer to the } \\
\text { court: Art 15 }\end{array}$ & $\begin{array}{l}\text { Transfer to the } \\
\text { court: Art 15 }\end{array}$ & \\
\hline $\begin{array}{l}\text { MAINTENANCE } \\
\text { BETWEEN } \\
\text { SPOUSES } \\
\text { (Maintenance } \\
\text { Regulation) }\end{array}$ & $\begin{array}{l}\text { General rule: } \\
\text { Art 3 lett. c) } \\
\text { Choice of } \\
\text { court: Art 4 } \\
\text { lett. b), c) 1st } \\
\text { indent }\end{array}$ & $\begin{array}{l}\text { General rule: } \\
\text { Art 3 lett. b) } \\
\text { or c) } \\
\text { Choice of } \\
\text { court: Art 4 } \\
\text { lett. a), b), c) } \\
\text { 1st indent }\end{array}$ & $\begin{array}{l}\text { General rule: } \\
\text { art 3 lett. a) } \\
\text { or c) } \\
\text { Choice of } \\
\text { court: Art 4 } \\
\text { lett. a), c) 1st } \\
\text { indent }\end{array}$ & $\begin{array}{l}\text { Choice of } \\
\text { court: Art 4 } \\
\text { lett. c) 2nd } \\
\text { indent }\end{array}$ & \\
\hline $\begin{array}{l}\text { MAINTENANCE } \\
\text { TOWARDS A } \\
\text { CHILD } \\
\text { (Maintenance } \\
\text { Regulation) }\end{array}$ & & $\begin{array}{l}\text { General rule: } \\
\text { Art 3 lett. b) } \\
\text { or d) }\end{array}$ & $\begin{array}{l}\text { General rule: } \\
\text { Art 3 lett. a) }\end{array}$ & & \\
& & & & \\
\end{tabular}

${ }^{53}$ Article 7 of the Regulation on Property Consequences of Registered Partnerships.

54 Article 6, lett. e) of the Regulation on Property Consequences of Registered Partnerships. 


\begin{tabular}{|c|c|c|c|c|c|}
\hline & Austria & Spain & Germany & Italy & France \\
\hline \begin{tabular}{|l|} 
PROPERTY \\
REGIME \\
(Regulation on \\
Matrimonial \\
Property Regimes)
\end{tabular} & \begin{tabular}{|l|} 
General rule: \\
Art 5 par 1 \\
Choice of \\
court: Art. 7 \\
referring to Art \\
22 lett. b) if the \\
parties choose \\
Austrian law
\end{tabular} & $\begin{array}{l}\text { General rule: } \\
\text { Art } 5 \text { par } 1 \text { (if } \\
\text { divorce is based } \\
\text { on Art } 3 \text { par } 1 \\
\text { lett. a) 3rd or } \\
4 \text { th indent of } \\
\text { BIIa) } \\
\text { General rule + } \\
\text { agreement: Art } \\
5 \text { par } 2 \text { lett. a) } \\
\text { or b) (if divorce } \\
\text { is based on Art } \\
3 \text { par } 1 \text { lett. } \\
\text { a) } 5 \text { th or 6th } \\
\text { indent of BIIa) } \\
\text {-> in absence } \\
\text { of agreement: } \\
\text { Art } 6 \text { lett. c) }\end{array}$ & $\begin{array}{l}\text { General rule: } \\
\text { Art } 5 \text { par } 1 \text { (if } \\
\text { divorce is based } \\
\text { on Art } 3 \text { par } 1 \\
\text { lett. a) 3rd or } \\
\text { 4th indent of } \\
\text { BIIa) } \\
\text { General rule } \\
\text { +agreement: } \\
\text { Art } 5 \text { par } 2 \text { lett. } \\
\text { a) (if divorce is } \\
\text { based on art } 3 \\
\text { par } 1 \text { lett. a) } 5 \text { th } \\
\text { indent of BIIa) } \\
\text {-> in absence } \\
\text { of agreement: } \\
\text { Art } 6 \text { lett. c) }\end{array}$ & $\begin{array}{l}\text { Choice of } \\
\text { court: Art } 7 \\
\text { referring to Art } \\
26 \text { lett. a) if the } \\
\text { parties choose } \\
\text { Italian law }\end{array}$ & $\begin{array}{l}\text { Choice of } \\
\text { court: Art } \\
7 \text { (place of } \\
\text { conclusion of } \\
\text { marriage) }\end{array}$ \\
\hline
\end{tabular}

18. One of three potentially competent Member State courts (Austria, Spain, and Germany) may be seised for divorce; but which of these three Member State courts will establish jurisdiction depends mainly on the will of one of the spouses. Thus, the time factor plays a significant role and such forum shopping may lead to "rush to court" tactics.

19. Custodial proceedings might be conducted only in Spain. The competent Spanish forum for parental responsibility matter does not have to coincide with a forum for divorce (here, Austrian or German). As a result, it would be necessity to file two legal actions in front of different Member States occurs. Thus, Articles 12 and 15 of the Brussels IIa Regulation are the unique, effective solutions for concentrating the proceedings in divorce and parental responsibility matters. However, the Brussels IIa Regulation does not contain an opposite rule enabling parties to seise a Member State court for divorce proceedings in a Member State court competent for parental responsibility matters, which would guarantee the hearing of the case in a Member States court in accordance with the best interest of child based on the proximity principle. As a consequence, the "centre" of both proceedings becomes the Member State court competent for divorce by virtue of Article 12 or 15 of the Brussels IIa Regulation.

20. As to the relationship between maintenance, divorce, and parental responsibility proceedings, it must be highlighted that maintenance proceedings often follow the proceedings for parental responsibility matters or divorce in accordance with Article 3, lett. c) or lett. d) of the Maintenance Regulation. This means that if an Austrian, Spanish, or German court is seised for divorce, the same Member State courts may have jurisdiction for maintenance obligations between the spouses, and the Spanish court might establish jurisdiction for maintenance obligation towards a child. However, the commencement of the maintenance proceedings in a Member State court different from a Member State court competent for parental responsibility, or even for divorce in accordance with Article 3, lett. a) or lett. b) of the Maintenance Regulation, comes into play as well. As a consequence, three different competent Member State courts might be seised in this stage - jurisdiction for divorce might lie in an Austrian court, for parental responsibility in a Spanish court, and for maintenance in a German court. On the other hand, Article 3 of the Maintenance regulation is friendly to creditors and respects the will of the maintenance creditor. However, a questionnaire conducted within the framework of EUFam's project, ${ }^{55}$ which was distributed to practitioners and academics from 17 Member States, found that the most fre-

55 See Answer to the question no 15 of Report on the outcomes of the online questionnaire of EUFam's available at: http:// www.eufams.unimi.it/2017/06/01/report-outcomes-online-questionnaire/ (accessed on 5 June 2017). 
quent jurisdiction that was expressly referred to and applied in practise was Article 3, lett. a) $(73,21 \%$ selected and utilized the respondent's habitual residence). Thus, it is important to pose a question - why does a maintenance creditor have an interest in filing a motion in front of non-home forum? This may be because the maintenance creditor was sufficiently informed in order to predict potential favourable legal consequences of commencing proceedings in a court of debtor's habitual residence, taking into consideration application of the law of the forum according to Article 4 par. 2 of the Maintenance Protocol. Or it may be due to the lack of knowledge or information of the maintenance creditor as the potential weaker party and insufficient financial resources in order to obtain qualified information, due to causing application of Article 3, lett. a) in connection with Article 4 par. 2 of the Maintenance Protocol. Furthermore, an Italian court may also establish jurisdiction by common agreement of the spouses for spousal maintenance allowance.

21. The jurisdictional grounds for matters of matrimonial property regimes seem to be more complicated for non-practitioners. ${ }^{56}$ In the majority of cases, the forum of matrimonial property regimes matters follows forum for divorce in accordance with Article 5, par. 1 of the Regulation on Matrimonial Property Regimes. In our example, the Austrian court competent for divorce, in accordance with Article 3, par. 1, lett. b) of the Brussels IIa Regulation, or the German or Spanish courts competent for divorce, in accordance with Article 3 par 1 lett. a) 3rd or 4th indent of Brussels IIa Regulation, will be competent automatically for the dissolution and liquidation matrimonial property regimes. However, if divorce proceedings are commenced in a Member State according to the fifth or sixth indent of Article 3, par. 1, lett. a), then the agreement of the spouses is required in order to seise the same Member State court (i.e., German or Spanish courts) for the dissolution and liquidation matrimonial property regimes. Moreover, besides an agreement on jurisdiction in favour of German or Spanish courts, the spouses may also agree on Austrian or Italian courts, or if lex fori applies, on French court representing the place of the conclusion of marriage. When an agreement of the spouses by virtue of Articles 5 or 7 is not possible, then the hierarchical scale of the jurisdictional ground determines the competent court by virtue of Article 6 . In our specific case, whether jurisdiction will lie in German or Spanish courts will be dependent on which spouse files an action as the first because the respondent enjoys a better position ensured by Article 6 , lett. c). The system of jurisdictional grounds provided in the Regulation on Matrimonial Property Regimes does not seem to be simple and comprehensible for affected individuals. Time will reveal if the application of jurisdictional grounds cause problems in practise even for legal practitioners.

22. It is evident from the table that up to five Member State might be seised in order to decide all aspects of family life. However, such a scenario is not very probable, since common agreement of the spouses would be required in favour of two different Member State courts. It seems more likely that proceedings in two or three Member State courts might take place quite often in practise for interrelated family matters. It must be stressed that choice has a decision role for one of seven jurisdictional grounds for divorce established in Article 3 of the Brussels IIa Regulation in order to concentrate divorce forum with other "linked" proceedings - proceedings concerning maintenance between the spouses and matrimonial property regimes. Moreover, when one of the exceptions to the general rule on parental responsibility set out in Article 12 or 15 of the Brusssels IIa Regulation applies, the divorce proceedings may be joined with parental responsibility proceedings. As a consequence, jurisdiction on child maintenance may "pass" on a court that has jurisdiction in divorce through application of Article 12 or 15 of the Brussels IIa Regulation in connection with Article 3 d) of the Maintenance Regulation. Such a result can be reached only in the presence of a jurisdictional agreement on custody and if the maintenance creditor

56 On the interaction among the proposals on Regulations on Property Regimes and other EU instruments see: A. Bonomi,"The Interaction among the Future EU Instruments on Matrimonial Property, Registered Partnerships and Successions" in Yearbook of Private International Law, Sellier European Law Publishers, No 13, 2011, pp. 217-232.B. C. DíAz, "The Coordination of the EU Regulations on Divorce and Legal Separation with the Proposal on Matrimonial Property Regimes“ in Yearbook of Private International Law, Sellier European Law Publishers, No 13, 2011, pp. 233-254, J. Gray / P. Q. REDONDO, "Stress-Testing the EU Proposal on Matrimonial Property Regimes: Co-operation between EU private international law instruments on family matters and succession“", in Family \& Law November, 2013, DOI: 10.5553/FenR/.000011. 
chooses to connect all family proceedings. The doubts derive from the question on the most appropriate forum - is the divorce venue best placed to hear a case on parental responsibility, subject to a critique on the existence of certain jurisdictional grounds for divorce and creating abusive procedural tactics?

\section{Coherence with Domestic Law}

23. It is not surprising, that still sometimes the Member State courts apply immediately national rules without previous examination of jurisdiction on the basis of EU regulations. ${ }^{57}$ Some Member State courts also concentrate divorce, maintenance obligations and parental responsibility matters in the same proceedings for divorce according to the Brussels IIa Regulation, i.e. divorce proceedings is extended to the maintenance or parental responsibility matters. ${ }^{58}$

24. However, the aim of this article is not to analyse all underlined problems connected with application of EU regulations in front of the Member States, but to test the functionality of the EU regulations on different aspects of family life, resulting in commencement of interrelated proceedings in multiple Member States, and their coherence with national procedural law. The endurance test of proper application of jurisdictional rules on divorce, parental responsibility, maintenance, and property regimes resulting in proceedings in multiple Member States will be provided through simultaneous application of domestic rules of the Member State. Two types of domestic rules will be examined: one requires all family matters to be heard in a single "package" (Slovakia); and the other is a Member State where a previous determination of custody rights serves as a condition for issuing a judgment for divorce (Czech Republic).

\section{Slovakia}

24. According to Slovak law, matters relating to divorce, maintenance, and parental responsibility have to be decided in unique proceedings. Article 24, par. 1 of the Act No 36/2005 Coll. on Family law provides:

The court shall determine parental rights and responsibilities toward the child for a time after the divorce in the judgment for divorce, in particular the court shall determine in such judgment who has custody rights over a child and who represents and administers child's assets. Simultaneously, the court shall approve the parents' agreement on maintenance obligation or shall order maintenance to a parent whom a child was not entrusted into the personal care. ${ }^{59}$

In other words, when the spouses have children, the court is always obliged to determine custody and visitation rights regarding a child and child maintenance before issuing a judgment for divorce. Thus, a custody order and judgment for child maintenance allowance are conditions for a subsequent judgment for divorce. Moreover, Article 100 of Act No 161/2015 on Civil Procedure expressly provides that proceedings for determination of parental responsibility after the divorce is connected with the divorce proceedings. ${ }^{60}$

25. By virtue of EU legal instruments on family matters prevailing over the national-law rules, the Slovak courts are often obliged to exclude certain family matters (parental responsibility, maintenan-

57 Immediate application of national rules without previous examination of jurisdiction on the basis of EU regulations may be named as examples, see: Judgment of: Audiencia Provincial Barcelona, 4 February 2015, 53/2015, EUFam's number: ESS20150204; Audiencia Provincial Islas Baleares, 2 March 2015, 77/2015, EUFam's number: EES20150302; Audiencia Provincial Barcelona, 20 October 2015, 661/2015, EUFam's number: ESS20151020.

58 Judgment of Audiencia Provincial Barcelona, 18 July 2013, 551/2013, Eufam's number: ESS20130718. The court correctly established jurisdiction for divorce according to Article 3 par. 1 of the Brussels IIa Regulation, but did not make any reference to jurisdiction over maintenance and parental responsibility.

${ }^{59}$ Informal translation was provided by the author for the purpose of this article.

60 Act No 99/1963 on Civil Procedure was replaced on 1 July 2016 by Act No 161/2015 on Civil Procedure. Article 100 of Act No 161/2015 on Civil Procedure and is identical to Article 113 of the Act No 99/1963 on Civil Procedure. 
ce, etc.) from a single hearing. However, separation of proceedings from unique family proceedings is not known to Slovak law. As a consequence, the practice of Slovak courts experience difficulties arising from a "split" of the proceedings and tend to concentrate divorce and parental responsibility into the same proceedings; or, on the contrary they declare lack of jurisdiction when the concentration of jurisdiction in all subject matters is not possible.

26. The judgment of Krajsky súd Bratislava dealt with the problem of a split of the maintenance matter from the "unique family proceedings". ${ }^{61}$ Both parties of the proceedings were Slovak citizens, but the mother and child were habitually resident in Hungary and the father in Slovakia. The Slovak court was seised for the divorce. The applicant was invited by the court to complement the action for divorce with an action for child maintenance. ${ }^{62}$ Okresný súd Bratislava II, as the court of first instance, by virtue of Slovak law, required the concentration of jurisdiction on both matters, and thus declared a lack of jurisdiction in both the divorce and parental responsibility matters. The court came to this conclusion even though jurisdiction over the divorce was with the Slovak court, according to Article 3 par. 1 lett. a) and 3 par. 1 lett. b) of the Brussels IIa Regulation. ${ }^{63}$ The Krajský súd Bratislava, as a court of appeal, correctly annulled the decision of the court of first instance and referred the case back for further consideration. ${ }^{64}$ According to the opinion of court of appeal, the EU regulations had priority over the national law and therefore, the court of first instance was not allowed to decline jurisdiction regarding divorce only due to the lack of jurisdiction in parental responsibility matters.

27. However, as to the maintenance the Slovak court of appeal stated:

...determination of child support obligation must precede the custody order... In case that previous custody order is absent, it is not possible to determine which parent is obliged to pay child support since it is not apparent which parent has child custody right. The appellant cannot have knowledge who is obliged to pay child maintenance, i.e. who is defendant, since custody order is absent. ${ }^{65}$

In this regard, it is opportune to deal with a question on the notion of maintenance creditor and debtor, and if a judgment on child support should precede the custody order.

28. The question was partially answered by the ECJ in case C-295/95, Jackie Farrell v James Long $^{66}$ which interpreted the term "maintenance creditor" in Article 5 n. 2 of the Brussels Convention. ${ }^{67}$ The court stated that "maintenance creditor" must be interpreted autonomously and "covers any person applying for maintenance, including a person bringing a maintenance action for the first time... ${ }^{68}$ without

${ }^{61}$ Krajský súd Bratislava, 13 January 2014, 11 CoP/326/2013, EUFam's number: SKS20140113.

${ }^{62}$ As quoted above, Article 24 of Family Act provides that custody and visitation rights and maintenance must be determined in the judgment concerning divorce. In the judgment, a reference is made to Krajský súd Trnava, 17 December 2012, 10 $\mathrm{NcC} / 28 / 2012$, however this decision is not available.

63 The court of first instance failed to identify jurisdiction in child maintenance, pursuant to the Maintenance Regulation.

${ }^{64}$ See opposite approach of the Slovak court in Krajský súd Bratislava, 30 September 2011, 5 Co 414/2011, EUFam's number: SKS20110930. Krajský súd Bratislava expressly stated that as a consequence of the necessity to provide for the unique proceedings in accordance with Slovak family law, and due to the fact that jurisdiction according to Article 3, par. 1, lett. b) of the Brussels IIa Regulation is with the Slovak courts as well as with Austrian court according to Article 3, par. 1, lett. a) of the Brussels II a Regulation, an Austrian court may establish jurisdiction also for parental responsibility; then, the Slovak courts are entitled to declare lack of jurisdiction since there is another Member State court that may decide the dispute.

${ }^{65}$ Krajský súd Bratislava, 13 January 2014, op. cit., p. 6.

66 ECJ, Jackie Farrell, C-295/95, op. cit.

${ }^{67}$ On the notion of maintenance creditor see also: P. JENARD, Report on the Convention on jurisdiction and the enforcement of judgments in civil and commercial matters, OJEC C 59, 5 March 1979, p. 25, (“Jenard Report"), P. MANKOWSKI in U. Magnus, P. MAnKowski (eds.), Brussels I Regulation, Munchen, Sellier, 2007, pp. 175; F. Pesce, Le obbligazioni alimentari tra diritto internazionale e diritto dell'Unione europea, Roma, ARACNE, 2003, p. 84, , F. PEsCE, "Tutela del creditore di alimenti nel diritto internazionale privato dell'Unione europea" in I. QueIrolo, A. M. BenedetTi, L. CARPANeto (eds.), La tutela dei soggetti deboli tra diritto internazionale, dell'Unione europea e diritto interno, Roma, ARACNE, 2012, pp. 483.

68 ECJ, Jackie Farrell, C-295/95, op. cit., para 27. 
having previously obtained a judicial decision recognizing his or her entitlement to maintenance". ${ }^{69}$ The interpretation provided by the ECJ was given in context of Article 5 para. 2 of the Brussels Convention regarding jurisdiction based on habitual residence of the maintenance creditor "which is in the best position to know whether the creditor is in need and to determine the extent of such need." maintenance, the venue for parental responsibility will coincide with the venue of a maintenance creditor, and as a consequence no particular difficulties will arise. However, the ECJ case did not touch on the question of opposite situation, when a Member State court in the place of habitual residence of the respondent, (i.e. in a place of habitual residence of maintenance debtor), is seised by maintenance creditor.

29. We may demonstrate practical problems in a subsequent scenario: the court of Member State A is a place of habitual residence of the father and is seised according to Article 3 lett. a) of the Maintenance Regulation by the mother. However, the hearing regarding custody is pending according to Article 8 of the Brussels I Regulation in front of the court of Member State B where the proceedings are very slow (application of Article 12 and 15 of the Brussels IIa Regulation is not possible). The family relationship is not clear prima facie and both parents request sole custody. It is true that a debt is an obligation arising from a fact which may be either a legal fact or a legal act. But in this specific case, a legal act does not exist and the legal fact is dependent on findings made by a court in Member State $\mathrm{B}$, which may confer shared custody or sole custody to any of the parents. ${ }^{71}$ How should the court of Member State A proceed?

30. There are two possible options. Firstly, Member State A might make its own considerations on the status of the parties and directly issues a maintenance order, which is subsequently enforceable due to the prohibition against a review as to the substance. ${ }^{72}$ Professor Jenard argued that any difficulties should be considered in the chapter on recognition and enforcement of judgments. However, it is possible to rely on such an option only in case of-cross border recognition or enforcement of the judgment within the grounds for non-recognition of Article 24 of the Maintenance Regulation. ${ }^{73}$ Indeed, when a previously issued child-support order is not in line with the subsequent custody order, motion for modification of child support will be necessary; until that time the child support will represent an enforceable legal title. Such an option does not seem to respect the principle of procedural economy. Secondly, Member State A might suspend proceedings, according to national procedural rules if they permit so, or impose provisional measures for an indeterminate period until the time that Member State B decides custody. This option is more flexible, but results in an inevitable period of latency. ${ }^{74}$

31. The Slovak court concluded its consideration regarding application of Article 3 lett. d) of the Maintenance Regulation in the context of concentration of jurisdiction:

[O]nly application of article 3, lett. d) of the Maintenance Regulation must be taken into consideration as the only reasonable solution guaranteeing the Slovak courts not to circumvent provisions of national law requiring determination of all complex of parental responsibility rights in divorce proceedings. This jurisdictional ground prevents determining the child support without any previous decision recognizing entitlement to maintenance in divorce proceedings. ${ }^{75}$

${ }^{69}$ ECJ, Jackie Farrell, C-295/95, op. cit., para 21.

70 ECJ Jackie Farrell, C-295/95, op. cit., para. 24 referring to the Jenard Report, p. 25.

71 See Opinion of Advocat General Léger delivered on 12 December 1996 concerning case Jackie Farrell, note 54.

72 Art. 42 of the Maintenance Regulation.

73 Art. 27 para 4 of the Brussels Convention allows for re-examining whether the court which gave judgment on the maintenance claims had jurisdiction under the provisions of Title II and to not recognize such a judgment. See also Schlosser Report, op. cit., para 35 or A. LAYTON / H. MERCER, European civil practice, London, Thomson/Sweet \& Maxwell, 2004 , p. 467.

74 See Opinion of Advocat General Bot delivered on 16 April 2015, concerning case $A v B$, note 49; the Advocat General held that continuity between the different phases of the proceedings must be ensured and unacceptable delays imposing measures for an indeterminate period are in breach of the principle of the best interests of the child.

${ }^{75}$ Krajský súd Bratislava, 13 January 2014, op. cit., p. 7. 
The Slovak court did not tackle the issue of concentrating divorce with child support proceedings according to Article 3, lett. c) of the Maintenance Regulation which provides that: "jurisdiction shall lie with the court which, according to its own law, has jurisdiction to entertain proceedings concerning the status of a person if the matter relating to maintenance is ancillary to those proceedings... "'76 However, the question arises if it would be entitled to do so.

32. The Maintenance Regulation does not specify if this jurisdictional ground finds application only in context of maintenance between the spouses, and the valuation on application of this jurisdictional ground is subject to lex fori covering private international law. ${ }^{77}$ According to the Slovak law, proceedings on child support are linked with proceedings concerning the status of a person. Additionally, provisions requiring joint proceedings of divorce and child maintenance matters may be found also in other Member States. ${ }^{78}$ However, the ECJ in case $A v B$ held that when one Member State court was seised in accordance with Article 3, lett. c) and other one in accordance with Article 3 lett. d), proceedings relating to maintenance concerning that child were ancillary only to the proceedings concerning parental responsibility. ${ }^{79}$ Although the ECJ excluded discretion in interpreting of the scope of the "ancillary matter" by the courts of Member to their national law,${ }^{80}$ this interpretation leaves some questions.

33. Firstly, maintenance obligations, which according to the ECJ are "not necessarily linked to divorce proceedings" might be linked in individual cases shaped by the best interest of the child. ${ }^{81}$ Secondly, the jurisdictional grounds set out in Article 3 of the Maintenance Regulation are alternative and are linked by the conjunction "or" ${ }^{82}$ Thirdly, doubts arise whether this interpretation is applicable when only one Member State is seised for divorce and child allowance - the ECJ dealt with positive conflict of jurisdiction between two already seised Member States by virtue of Article 3 lett. c) and lett. d). ${ }^{83}$ Sometimes the parents do not intend to determine judicially the custody and visitation rights and they rather maintain voluntary, mutual agreement on visitation rights; they would accede to concentrating divorce and child allowance proceedings when the child's best interests are undisputable (nationality, family, language, etc.). The paradox of the situation is evident - the divorce forum may hear a parental responsibility case through application of Article 12 of the Brussels IIa Regulation and subsequently the divorce forum may hear a case on child allowance according to Article 3 lett. d) of the Maintenance Regulation, which practically results through application of Article 3 lett. c).

76 This provision was added into Article 5 para. 2 of the Brussels Convention by the 1978 Accession Convention to accommodate the provisions of United Kingdom law. See A. LaYton / H. Mercer, European civil practice, London, Thomson/ Sweet \& Maxwell, 2004, p. 466.

77 See Schlossser Report, op. cit., para 40 or P. Mankowski in U. Magnus, P. Mankowski (eds.), Brussels I Regulation, op. cit., p. 178: "whether a joint hearing and a joint treatment of status proceedings and maintenance proceedings is permitted must be answered by the national procedural rules of the forum".

78 E.g., on the topic of Joinder of Divorce Proceedings and Ancillary Proceedings in Germany in the context of application of Article 5 para 2 of the Brussels I Regulation see S. LeIBLE in: T. RAuscher, Europäisches Zivilprozeßrecht: Bd. 1: Brüssel I-VO, Brüssel IIa-VO, München, Sellier, 2006, p. 193. See also Section 137 of German Act on Proceedings in Family Matters and in Matters of Non-Contentious Jurisdiction of 17 December 2008, which provides that divorce and ancillary proceedings (maintenance and support proceedings, to the extent there is a duty of support in respect of common children or statutory maintenance arising from the establishment of the marriage, with the exception of simplified proceedings concerning support for minors) are to be argued and decided together. In Hungary and Poland, maintenance is ancillary to the custody proceedings, see in this regard the Heidelberg Report, op. cit., p. 39. In Estonia, divorce matters, custody matters, and maintenance matters can all be dealt with in one proceeding, see Assessment Study, op. cit., p. 10.

79 ECJ, 16 July 2015, $A v B$., C-184/14, ECLI:EU:C:2015:479, note 27.

$80 \mathrm{ECJ}, A \vee B$., C-184/14, op. cit., note 30.

81 ECJ, $A v$ B., C-184/14, op. cit., note 40. See also J. BorG-BARTHET, Jurisdiction in matrimonial matters - Reflections for the review of the Brussels II Regulation (Study for the JURI Committee), op. cit., p. 10, with respect to the case of ECJ, $A v$ $B$ the author stated: "In practical terms, however, the fact that maintenance obligations are "not necessarily linked to divorce proceedings' does not of itself mean that they might not be linked in individual cases.".

82 ECJ, $A v B$., C-184/14, op. cit., note 34 where the ECJ held that from the wording of Article 3 of the Maintenance Regulation it cannot established whether the alternative nature of criteria means that the applications relating to child maintenance are ancillary only to one set of proceedings concerning parental responsibility, or whether those applications may be deemed ancillary also to proceedings concerning the status of a person.

83 ECJ, $A v B$., C-184/14, op. cit., note 47. 


\section{Czech Republic}

34. The same or similar national rules as in Slovakia are in the Czech legal system. ${ }^{84}$ The national rules of family law in the Czech Republic do not require the unique hearing for divorce, parental responsibility, and maintenance as in Slovakia. However, Article 755 of the Act No 89/2012 Coll., Civil Code $^{85}$ requires a previous determination of custody rights over the children which must be fulfilled in order to issue a judgment on divorce, and thus guaranteeing protection of the minor child ${ }^{86}$ Article 755 , par. 3 of New Civil Code specifies: "If spouses have a minor child who has not yet acquired full legal capacity, the court shall not issue a judgment for divorce until it decides on the means of the child for the period after divorce." ${ }^{87}$ Even if the condition is regulated by Czech substantive law, the text of the provision "the court shall not issue a judgment for divorce until..." indicates a procedural nature and foreign applicable law will not have an impact on the conduct of proceedings. As a consequence, if the custody proceedings takes place in a different Member State and is unusually long, the divorce proceedings in the Czech Republic may be blocked for several years. ${ }^{88}$

35. As to child maintenance, Article 755 of the New Civil Code (in opposition to the Family Act before re-codification of Czech civil law ${ }^{89}$ ) does not expressly mention determination of child maintenance as a condition required for a divorce judgment. However, it is presumed from the wording of New Civil Code, in combination with Act No 292/2013 on Special Judicial Proceeding, that child maintenance proceedings together with custody and access proceedings form parts of the "proceedings in matters of custody court for minors" and must precede the divorce proceedings. ${ }^{90}$ The question arises if a Czech court must stay divorce proceedings until a Member State different from a Member State competent over the parental responsibility issues a judgment on child maintenance. ${ }^{91}$

36. It is necessary to emphasise that above-mentioned provisions of the Czech New Civil Code have a significant impact on the matrimonial property regime of the spouses..$^{92}$ The common property of spouses will increase or will be reduced during the latency period for judgment for divorce issued by Czech court, which will be dependent on the length of latency period for custody order issued by another

${ }^{84}$ The unique proceedings for divorce, parental responsibility, and maintenance was required by the Czech Family Act until 1 August 1998, until amendment No 97/1998 to the Act No 97/1963 Coll., on Family Law, became effective. See in this respect: Opinion of Civil and Commercial Division of the Supreme Court of the Czech Republic on child custody in connection with divorce proceedings, 14 April 2010, Cpjn 204/2008, R 52/2010 civ. On differences between the Slovak and Czech Family Act after the amendment see: M. HRušÁKovÁ, Zákon o rodině. Zákon o registrovaném partnerství. Komentár Beck, 2009, p. 99.

${ }^{85}$ Act No 97/1963 Coll. on Family Law ("Family Law Act") was replaced by the Act No 89/2012 Coll., Civil Code ("New Civil Code") which became effective on 1 January 2014. According to Article 3028 of New Civil Code, the rights and the duties which arose after its effective date are governed by the New Civil Code; however the creation of these relations, as well as the rights and duties which arose from them before the effective date of the New Civil Code must be assessed under current legal regulations.

86 Milana Hrušaková / Lenka Westphalová, Family law in the Czech Republic, The Netherlands, Kluwer Law International, 2011, p. 86.

87 The wording of the text "decides on the situation of the child at the period after the divorce" must be interpreted as judgment of the court regarding the custody over the child. English translation of the New Civil Code is available at: http:// obcanskyzakonik.justice.cz./images/pdf/Civil-Code.pdf.

${ }^{88}$ See in this context e.g., ECJ, 9 December 2003, C-116/02, Erich Gasser GmbH, ECR I-14693, where it was pointed out that some Member States have excessively slow proceedings.

89 Article 26 of the Family Act expressly required, as a condition for divorce, a previous custody order and the determination of child maintenance obligations.

90 See judgment of Krajský soud v Plzni, 9 November 2015, 10 Co 325/2015, and its commentary by K. SvoBoda, Soudni rozhledy, 2/2014, p. 50; or commentary to article 910 of New Civil Code: M. HrušÁKovÁ, Z. KráLíčKovÁ, L. WestPHALOvÁ, Občanský zákoník II. Rodinné právo (§ 655-975). Komentářr., Praha, C. H. Beck, 2014, p. 1044.

91 The national case law did not note any problem regarding the split of the child maintenance proceedings from the custody proceedings.

${ }^{92}$ Article 709 of the New Civil Code provides for the term of "statutory matrimonial property" that includes property acquired during the marriage by one of the spouses individually or by both spouses with certain exceptions Article 716 of the New Civil Code then creates a matrimonial property regime different from the statutory regime, i.e., contractual property regime of the spouses requiring mutual agreement of the parties. 
Member State court. Practically, it results in a vicious circle of the Member State courts which must stay proceedings. For instance, the court of Member State A hears the dispute over the parental responsibility, but a Czech court is competent over the divorce, and Member State $\mathrm{C}$ must establish jurisdiction on the matrimonial property regime in accordance with national PIL Acts, or according to Article 6 or 7 of the Regulation on Matrimonial Property Regimes after 29 January 2019.93

\section{Conclusions and considerations de lege ferenda}

37. This article demonstrates that the application of different jurisdictional grounds in different EU regulations often leads to proceedings in multiple Member States in closely linked family matters. The solution of an EU legal instrument providing for a competent forum in all family matters seems to be unachievable in this moment. But, the effort to concentrate family proceedings is already evident in specific EU regulations (e.g., in the Regulation on Matrimonial Property Regimes or in the Maintenance Regulation). However, such efforts do not always guarantee the concentration of jurisdiction in one Member State court, even when such a forum would be an appropriate one. ${ }^{44}$ Articles 12 or 15 of the Brussels IIa Regulation may be perceived as alternative solutions for connecting litigation for major parts of family matters in one Member State. Then, the divorce venue becomes the "centre" of other interrelated family proceedings - for parental responsibility in accordance with Article 12 or 15 of the Brussels IIa Regulation, for maintenance in accordance with Article 3 lett. c) and d) of the Maintenance Regulation, and for matrimonial property regime in accordance with Article 5 of Regulation on Matrimonial Property Regimes - if all conditions for their application are satisfied. However, do Articles 12 and 15 of the Brussels IIa Regulation fully respect the best interest of the child? A more reasonable option would be the introduction of the provision enabling concentration of interrelated family matters in a court competent for parental responsibility. For example, parties may use a choice-of-court agreement or legislators may create a hierarchical scale between jurisdictional grounds in Article 3 of the Brussels IIa Regulation awarding priority to court of a Member State having jurisdiction over parental responsibility matters. Unfortunately, in light of the discussion regarding the Proposal of the Brussels IIa Regulation, the current situation does not seem to be changing in the near future.

38. Last but not at least, it must be stressed that fragmentation of EU legal instruments appears to be even more problematic when applying national procedural rules. The domestic case law has indicated not only the non-application of specific rules established by EU regulations in cases of conflicting rules, but incoherence between domestic and EU law that results in problematic situations. Firstly, the Slovak case law has revealed that unclear legal facts concerning maintenance creditors and the absence of legal acts on custody renders it difficult to apply the jurisdictional ground laid down in Article 3 lett. a) and b) of the Maintenance Regulation. The solution for this problem could be that Article 3 lett. a) and lett. b) would represent the unique jurisdictional grounds governing situations in which the application concerning child maintenance obligations is the main action, ${ }^{95}$ while Article 3 lett. c) and d) would represent two grounds for jurisdiction when the child maintenance is ancillary to custody. Thus, such a division should ensure that custody and child maintenance actions will be the basis of single venue respecting the principle of best interest of the child based on proximity. In this respect, the Maintenance Regulation should be also amended in order to clarify if lett. c) is not applicable for child maintenance allowances without any exceptions and set aside any doubts resulting from the $A v B$ case. Secondly, the

${ }^{93}$ See Study in comparative law on the rules governing conflicts of jurisdiction and laws on matrimonial property regimes and the implementation for property issues of the separation of unmarried couples in the Member States, 30 April 2003, ASSER-UCL Consortium commissioned by the Commission, available at http://europa.eu.int/comm/justice_home/doc_centre/ civil/studies/doc_civil_studies_en.htm.

${ }^{94}$ G. Moir / P.R. Beaumont, "Brussels Convention II: a new private international law instrument in family matters for the European Union or the European Community?", op. cit., p. 9, according to the authors, the ideal solution for the court hearing is the divorce action be connected with matrimonial property, and financial and social aspects relating to children of the marriage.

${ }^{95}$ See Opinion of Advocat General Bot delivered on 16 April 2015 concerning case $A v B$, note 41 . 
Czech legislation highlighted the incoherence between the rules on parental responsibility and divorce pursuant to the Brussels IIa Regulation and national rules on divorce protecting the interest of the child. The incoherence does not circumvent the proper application of EU rules, but might result in excessively long waiting periods. However, in this case a solution should be found on the national level, and obstacles or incoherence from national substantial or procedural family law should be removed.

39. In conclusion, the fragmentation of jurisdiction in different Member States cannot be always classified as a negative effect arising from the diversity of jurisdictional ground in family matters, since the scope of certain rules is the protection of fundamental principles (i.e., best interest of the child or the protection of the maintenance creditor). However, conducting proceedings in several Member States and the confusion caused by the fragmentation of the scope of jurisdiction in several EU regulations in family matters and mixing them up in single legal action may lead to the opposite result - to significant costs for weaker parties, or encouraging a wealth party to engage in abusive procedural tactics and disadvantaging the creditor. At least, a clear practical guidance for practitioners and for individuals should be adopted in order to clarify the legal framework of EU family law and the interrelationship of the Brussels IIa Regulation, the Maintenance Regulation, and the Regulations on Property Regimes. ${ }^{96}$ Lastly, further steps in order to harmonize national law in Europe should be taken. ${ }^{97}$

\footnotetext{
96 See Assessment Study, op. cit., p. 10.

97 See the Principles of European Family Law which are drafted by the Commission on European Family Law available at http://ceflonline.net/principles/.
} 